\title{
Genomic regions involved in productivity of two interspecific poplar families in Europe. 1. Stem height, circumference and volume
}

\author{
Sophie Y. Dillen • Véronique Storme - Nicolas Marron • \\ Catherine Bastien • Sabrina Neyrinck • \\ Marijke Steenackers • Reinhart Ceulemans • \\ Wout Boerjan
}

Published online: 5 February 2009

(C) Springer-Verlag 2009

Erratum to: Tree Genetics \& Genomes (2009) 5:147-164 DOI 10.1007/s11295-008-0175-8

The original version of this article unfortunately contained a mistake. The presentation of Table 1 was incorrect. The number 57 (in row 4, column 6) should be replaced by 579 . This is the correct result for Height 2 of the D x T family in France. The corrected table is given on the following page.

The online version of the original article can be found at http://dx.doi. org/10.1007/s11295-008-0175-8.

S. Y. Dillen $\cdot$ N. Marron $\cdot$ R. Ceulemans Department of Biology, University of Antwerp, Campus Drie Eiken, Research Group of Plant and Vegetation Ecology, Universiteitsplein 1,

2610 Wilrijk, Belgium

V. Storme $\cdot$ W. Boerjan $(\triangle)$

Department of Plant Systems Biology,

Flanders Institute for Biotechnology (VIB),

Technologiepark 927,

9052 Gent, Belgium

e-mail: woboe@psb.ugent.be

V. Storme $\cdot$ W. Boerjan

Department of Molecular Genetics, Ghent University,

9052 Gent, Belgium

C. Bastien

Unité Amélioration, Génétique et Physiologie Forestières,

Institut National de la Reserche Agronomique,

BP 20619, Ardon 45166 Olivet Cedex, France

S. Neyrinck $\cdot$ M. Steenackers

Research Institute for Nature and Forest,

Gaverstraat 4,

9500 Geraardsbergen, Belgium

Present address:

N. Marron

UMR 1137 INRA-UHP Écologie et écophysiologie forestières,

54280 Champenoux, France 
Table 1 Family means with standard error (SE), range of genotypic variation and heterosis for stemtraits related to plant growth at the end of the second growing season (height2, circum2, vol2, htcc2, deltaH and deltaC) for the $\mathrm{D} \times \mathrm{N}$ and $\mathrm{D} \times \mathrm{T}$ families in Cavallermaggiore (Italy) and Ardon (France)

\begin{tabular}{|c|c|c|c|c|c|c|c|}
\hline \multirow[t]{2}{*}{ Trait } & \multirow[t]{2}{*}{ Site } & \multicolumn{3}{|l|}{$\mathrm{D} \times \mathrm{N}$ family } & \multicolumn{3}{|l|}{$\mathrm{D} \times \mathrm{T}$ family } \\
\hline & & Mean \pm SE & Genotypic range & Mean heterosis $(\%)$ & Mean \pm SE & Genotypic range & Mean heterosis $(\%)$ \\
\hline \multirow[t]{2}{*}{ Height2 (cm) } & Italy & $631 \pm 4$ & $427-788$ & - & $746 \pm 4$ & $316-897$ & - \\
\hline & France & $459 \pm 2$ & $265-557$ & 16.1 & $579 \pm 3$ & $219-678$ & 22.5 \\
\hline \multirow[t]{2}{*}{ Circum2 (mm) } & Italy & $145 \pm 2$ & $75-212$ & - & $155 \pm 1$ & $73-216$ & - \\
\hline & France & $93 \pm 1$ & $50-133$ & 26.5 & $131 \pm 1$ & $42-165$ & 50.6 \\
\hline \multirow[t]{2}{*}{ Vol2 (dm3) } & Italy & $5.4 \pm 0.1$ & $1.1-10.6$ & - & $7.2 \pm 0.1$ & $0.9-13.4$ & - \\
\hline & France & $1.9 \pm 0.0$ & $0.5-4.0$ & 74.6 & $4.3 \pm 0.1$ & $0.3-6.7$ & 176.5 \\
\hline \multirow[t]{2}{*}{$\operatorname{Htcc} 2\left(\mathrm{~cm} \mathrm{~mm}^{-1}\right)$} & Italy & $4.43 \pm 0.04$ & $3.10-6.00$ & - & $4.94 \pm 0.02$ & $3.90-6.45$ & - \\
\hline & France & $5.02 \pm 0.02$ & $4.00-6.53$ & -11.1 & $4.56 \pm 0.02$ & $3.76-6.09$ & -17.6 \\
\hline \multirow{2}{*}{ DeltaH $(\mathrm{cm})$} & Italy & $368 \pm 3$ & $250-471$ & - & $479 \pm 3$ & $122-594$ & - \\
\hline & France & $238 \pm 2$ & $120-309$ & 21.1 & $291 \pm 2$ & $43-359$ & 43.0 \\
\hline \multirow[t]{2}{*}{ DeltaC (mm) } & Italy & $92 \pm 1$ & $42-145$ & - & $96 \pm 1$ & $29-148$ & - \\
\hline & France & $51 \pm 1$ & $23-82$ & 29.1 & $66 \pm 1$ & $8-88$ & 55.3 \\
\hline
\end{tabular}

Height $2=$ stem height at the end of the second growing season; Circum $2=$ stem circumference at $1 \mathrm{~m}$ above the ground level at the end of the second growing season; Vol2=estimated volume at the end of the second growing season; Htcc $2=$ ratio of stem height to circumference at the end of the second growing season; DeltaH=stem height at the end of the second growing season-stem height at the end of the first growing season; DeltaC=stem circumference at the end of the second growing season-stem circumference at the end of the first growing season. All differences between sites and families were significant at $P \leq 0.001$. Heterosis values at the Italian site were not calculated as no replicate of $P$. deltoides 'S9-2' and only two of $P$. nigra 'Ghoy' were alive at this site 